\title{
Abu Bakr Salem's Saudi-Hadhrami Songs in Translation
}

\author{
https://doi.org/10.33806/ijaes2000.20.2.13 \\ Adel Salem Bahameed \\ King Khalid University, Saudi Arabia
}

\begin{abstract}
This exploratory and descriptive study attempts to investigate Abu Bakr Salem's songs and poems to see how demanding the process of translating such poetic texts is. Three of the most authentic songs of the Saudi-Hadhrami famous singer have been translated and discussed to achieve the study goals which are refreshing translation studies with this regard as well as checking whether these Arabic songs are translatable. The translator was given much freedom to render this kind of challenging text which is loaded with cultural elements and prosodic features in the light of Low's (2005) Pentathlon Approach. The translator has done his best to manifest the aesthetic elements as far as possible. The findings are that folkloric Saudi-Hadhrami songs are untranslatable and the translation process is too complicated. Therefore, translators are not recommended to translate songs because a loss of meaning or form becomes something unavoidable. The intricacies lie mainly in manifold dimensions including cultural, colloquial, and prosodic aspects. In addition, the extra dimension of the music is beyond the translator's control.
\end{abstract}

Keywords: culture, poem, prosodic features, song translation, translation problem

\section{Introduction}

Cross-cultural aspects of translation studies have not been settled yet. A long controversial debate is still going on to handle these problematic issues. Scholars are still trying hard and keep in quest of knowledge that can support or refute the notion of whether cultural and literary elements are translatable and the differences between two cultures could be bridged. Decent endeavors to break the cultural barriers through translation have been made by many scholars including Hatim and Mason (1990: 223) who see translators as mediators between two cultures, and Vermeer (1989/2000) who believes that translators must be bicultural, if not multicultural. Moreover, this bilateral controversial relationship between culture and translation has also been discussed from general (Ghazala 2002), literary (Farghal and Borini 1998; Abdel-Hafez 2004), political (Shunnaq 2000), and religious (Faiq 1998; Homeidi 2004) perspectives.

On the other hand, poetry, lyrics, and songs are part and parcel of a nation's cultural heritage. Some translation theorists believe that poetry should not be translated and translators are not recommended to translate poetry because poetry consists of two elements which are tightly interwoven in the poem. These two elements are hard for the translator to convey in full from the source language (SL) into the target language (TL). These elements are form and content. The first 
element of the form includes using rhyme which means that the poet uses lexical items ending in the same sound. It also includes meter which indicates the arrangement of sounds in poetry into patterns of strong and weak beats. These prosodic matters are innately found in poems to give aesthetic touch and enjoyment to readers. The second element of the content refers to the meaning and ideas that are intended and expressed by the lexical items of the poem.

This being the case, one of these elements might be missed when trying hard to transfer the poem from one language into another. The translator may successfully transfer the form. But he/she might be reluctantly forced to sacrifice something related to the content. The opposite is also true. If the translator was so careful about the content, he/she may lose the aesthetic form of the poem. In both cases, the poem won't be rendered completely (Al-Jabri 2019: 1) and the translation will not make the same favorable aesthetic impact on the TL audience. Thus, "poetry is what gets lost in translation," says Robert Frost (as cited in Robinson, 2010, p. 24).

However, for the sake of sharing the beauty and enjoyment of poetry, lyrics, and songs with people of other languages and culture, attempts have been made by some translators despite the difficulties of translating this type of literary text. For instance, the widely famous Shakespearean sonnet "Shall I compare thee to a summers' day" has been translated into Arabic by Anani (2010) and Jawad (2018), among others. However, all these attempts did not reach the level required.

Indeed, our purpose from translating poems and songs is neither to reduce the importance of the poets' work nor the aesthetic elements of the original text. Our main aim is to share the beauty of poetry with people of other languages and cultures as a further step on the way towards narrowing the literary and cultural gap among different nations of the world. In the meantime, this study is hoped to introduce a deeper understanding of the area of the translatability or untranslatability of poetry and songs.

It should be noted that when a poem is sung using melodies and music, it means that the poem is aesthetically excellent and that it deserves the privilege to be sung. When the poem changes into a song, it will become famous and its popularity will rapidly increase by doubles in comparison with its popularity before it is sung (Gorlée 2005: 8). Not surprisingly, many poets have realized this fact and they have lost no time to contact famous musicians to market their products. This happens in the area of the SL atmosphere. However, transferring this song into a totally different TL atmosphere might not be possible.

When a poem and music meet, that particular poem would have a sense of oneness with music and both would constitute a unique entity that would rapidly change into a source of amusement that would give a good entertainment value to listeners. Furthermore, a translation could be used as a means to make such beauty concealed in these verbal poetic utterances accessible to readers worldwide. It is also a means of preserving and reviving an important part of the folkloric heritage of a certain area of the world (such as Saudi Arabia and Hadhramout) and saving it from sinking into oblivion (see also Anderson 2005). However, translating a folkloric song encapsulates accepting a challenge in which the translator must 
start an arduous journey through the three mountains of transferring the form, content, and music as precisely as possible; otherwise, the target audience won't receive the source aesthetic message in full (Dunbar 2002).

Realistically speaking, translating the third mountain of the music is a farfetched and unattainable dream. However, when the translator realizes that the wording of the poem is excellent and it could be sung, his focus turns over to translating the form including rhyme, rhythm, meter and the other prosodic features. This is simply because he/she would feel that the possibility of his translation to be sung is also high either using the same source melody or a different one, composed by a new TL musician (for more details about the possibility of translating music, see Shunnaq and Abul-Kas, 1998; and Golomb, 2005).

\section{Songs and translation}

Studies and approaches pertaining to the possibility of translating songs involving Arabic have been relatively few in number. Recent studies concerning song translation have focused mainly on other languages rather than Arabic. This might be due to a previous belief of some Arab researchers that translating Arabic songs is a thorny issue that might reach the point of untranslatability. Arabic and English belong to two language families which are totally different. Arabic is a Semitic language, while English is an Indo-European West Germanic Language. Thus, many challenges are expected to stand on the way of translators. The previous focus, consequently, includes translating songs from Finish into English (Kultti and Pramling 2018), from English into Persian (Aminoroaya and Amirian 2016), from Indonesian into English (Suharto and Subroto 2014), from Russian into English (Gritsenkoa and Aleshinskayab 2016), among others. In addition, the most prominent of these have appeared in the same year of 2005 such as (1) Low's (2005) Pentathlon Approach in which he admits that translating the song is a formidable challenge when compared to translating the lexical items of a poem or a lyric due to the fact that the music accompanying the song is also a relevant factor that should be conveyed as well to the TL. This is simply "because the target text must fit the pre-existing music - its rhythms, note-values, phrasings, and stresses - while still retaining the essence of the source text." (Low 2005: 185). Indeed, the gist of his argument is that full equivalence is surely impossible. However, attempts can still be made with some success if the translator's decision-making process has complied with the five different criteria of singability, sense, naturalness, rhythm, and rhyme. According to these guidelines, much room of freedom and flexibility is given to the translator to show creatively in his endeavors to uncover the meaning intended.

2) Franzon's (2005) Approach of Fidelity and Formatting has an interesting translation idea as he dichotomizes the notion of his approach into two concepts, called formatting (which focuses mainly on the element of form mentioned above) and fidelity (which focuses mainly on the element of content mentioned above), taking cultural differences into account. He believes that formatting should go in 
harmony with the translation strategy of "adaptation" (Franzon 2005: 265). Farghal and Shunnaq (1999:21) have clearly defined adaptation as "a translation method whereby the SL text is freely translated into the TL... and the SL culture is converted to the TL culture and the text is rewritten", so "formatting is what may transform a useless (literal) lyric translation into a singable and performable one" (Franzon 2005: 266). Al-Azzam and Al-Kharabsheh (2011:561) comment on the two concepts of this approach saying that "fidelity is a form of a literal translation of a song and format is the practice that qualifies it for performance, i.e. fidelity is the rendering of the entire verbal components of the SL, while formatting is concerned with non-verbal elements which make it presentable".

Additionally, Franzon (2005: 293) gives special consideration to using music as an extra dimension that may add insult to injury with regard to the intricacy of translating songs with success. In his approach, he tries to clarify and handle such a complicated issue regarding whether or not the text makes the music meaningful. The text suits the music with regard to harmonic progression by focusing on certain lexical items while the prosody fits the music with regard to vowel quality, stress, and intonation.

3) Kaindl's (2005) Approach which adopted a foundation, built basically by Philip Tagg (2000) who first suggests the use of a "hermeneutic-semiological method" which can "serve as a starting point for a translation-relevant analysis." This could be summed up in the following items:

a) aspects of time (e.g. tempo, meter, rhythm);

b) aspects of melody (e.g. timbre);

c) orchestration (e.g. instrumentation, voice type);

d) aspects of tonality and texture (e.g. harmony, relationships between voices and instruments);

e) dynamic aspects (e.g. audibility, accentuation);

f) acoustical aspects (e.g. the distance between the sound source and listener, simultaneous extraneous sounds);

g) electro musical and mechanical aspects (filtering, compressing, phasing, distortion, mixing). (Tagg 2000; quoted in Kaindl 2005: 245-246)

In fact, Kaindl regards every part of the production and reception of a song as great responsibility that should be fully taken into the translator's account. $\mathrm{He}$ supported this approach because he essentially believes in considering music as a system in translation. According to him, meanings are taken from the SL into the TL through lexical items and visual signs such as music, CD booklets, and video clips.

\section{The present study}

This exploratory study gives information about translating songs and poems and describes how this matter works in order to make it easier to understand, introducing a further step towards refreshing research endeavors in the field of translation. 
The advent of globalization is currently happening at the level of making business in multinational corporations, while the global interaction of cultural elements is still too limited. In an attempt to narrow the gap among cultures and make the non-Arabic nations get closer to the Arabic cultural heritage, this study was conducted. However, the thorny way that the translator must take to get Arabic poetry conveyed into the TL might get stuck with the issue of untranslatability and that is what this study aims to investigate.

Hadhramout (or Hadhramaut), as part of the Arab world, has long been considered a crude cultural material because, up to the moment, very little effort has been exerted to maintain and excavate the diversified branches of the rich intellectual and cultural heritage hidden there. Hadhrami researchers, let alone the others, have not shown much interest to work and explore this cultural reservoir. Many human aspects have, therefore, remained a mystery in the unknown world and have not received the deserving record, review, and criticism. Therefore, much work is required to explore, document and disseminate the originality, creativity and wealth of knowledge that it has (see Al-Sabban, 2001:5). The present paper is hoped to fill this gap as it concentrates on an important translation issue between Arabic and English, disclosing one cultural folkloric aspect in a new setting (i.e. Saudi Arabia and Hadhramout) and would share the informativity, creativity, and beauty of such songs and the favorable reactive pleasure they produce. It gives an ideal opportunity for revisiting research with regard to interlingua-intercultural mismatches emanating from re-formulating Saudi-Hadhrami songs and poems in the TL and giving one more proof whether or not poetry and songs are translatable with the existence of all the intricacies and thorns in this way.

This study concentrates on a selection of three authentic songs of Abu Bakr Salem, the most famous Saudi-Hadhrami singer and the Hadhrami poet Hussain Abubaker Al-Mehdar. These two persons are known to have constituted something like a singer-poet duo. They produced so splendid songs in Hadhramout at first. However, their production has spread to Saudi Arabia and all the Middle East. Their lyric creative production is really riveting and it deserves to receive all sorts of exploration, investigation, and review.

\subsection{Memoir of the singer}

Famous Saudi singer Abu Bakr Salem Belfkih was born on March 17, 1939 in Hadhramout. He moved to Saudi Arabia in the 1970s, traveling between Aden, Beirut, Jeddah, and Cairo until he settled in Riyadh and got the Saudi nationality. He was a singer, composer, poet, writer, and lyricist whose fame started in the 1970s and extended over many Arab neighboring countries. He, therefore, was given the nickname of "the father of the Arab Gulf Singing".

Abu Bakr Salem was awarded many medals, prizes, and honors. They included the "Golden Cassette" from a German distribution company. He won the UNESCO Prize as the first best voice in the world and the cultural medal in 2003. This is simply because, as a singer, Abu Bakr Salem gets a remarkable vocal 
ability to sing a note at exactly the correct level. He also can switch from one pitch into another quiet quickly with ease (Raffel 1986: 12). The University of Hadhramout also awarded him an honorary doctorate degree in 2003.

Yabiladiwassili (My country forge ahead) was the last song the late Abu Bakr Salem sang. It was sung during the Saudi National Day celebrations in September in Jeddah. He died on Sunday, aged 78, after terminal illness.

\subsection{Poet-singer duo}

It was in 1965 when this poet-singer duo met and launched their successful artistic journey towards shooting to fame. The poet, Al-mehdar, has written hundreds of poems with excellent wording that qualified them to change into lyrics to be sung with contemporary music. Al-mehdar published four books of poems, namely Lover's Tears (1966), Lover's Smiles (1978), Lovers' Melancholy (1999), and Lovers' Longing (1999). He was also a music composer that installed haunting melodies on his wording, constituting the main source and first supporter of his intimate singer, Abu Bakr Salem. What makes the duo mark important milestone is the decision of the latter to travel to the Saudi Arabia where he got better opportunities and facilities including a modern official musical band. Since then, he has gained wide entrance to the world of Arab countries music, utilizing the close similarity between his own Arabic dialect with the ones used in such geographically adjacent areas. Al-mehdar's aesthetic poems and melodies became more successful and riveting when sung by the golden voice of Abu Bakr Salem. In their complementary relationship, each one contributes to the increase of the artistic fame of the other, producing a collection of so interesting and exciting songs that one cannot stop listening to. They both constitute an undeniable source of pride for Arabs in general and Gulf countries in particular. The death of Almehdar in 2000 came as a tremendous shock to his constant companion as their warm artistic friendship lasted for more than three decades.

\section{Study method}

The study corpus used here is the three most authentic and famous songs of Abu Bakr Salem's, namely ياسهران yasahran (You Wakeful Lover!), زمانك zamanak (Your Time), and زاد عشقي zadishqi (My Love Increased). These songs and poems constitute a prominent culture-bound text type of Saudi Arabia and Hadhramout. Choosing these songs and poems, in particular, is mainly because they are among the songs and poems that are highly influential in the perception of SaudiHadhrami music, and are still actively stored in the memory of the people there. They are still fascinating to many people because of their expressive lexical items, captivating melodies, and popular rhythms.

These three famous songs have been carefully translated from Arabic into English by the researcher who is a professional translator and has been teaching translation courses at BA and MA university levels for more than 10 years.

Understanding the content of the songs' lyrics is not enough to produce "an acceptable" translation. The translator should keep an eye on the prosodic features as well. Special alternate prominence was placed on functional or pragmatic 
translation as well as literal or formal translation depending on the type of the translation mismatch being handled. The translation draws inspiration from Low's Pentathlon Approach.

Although Low's Approach is not that perfect, it remains the best option out of the existing approaches that suit the nature of this study. In other words, using the Pentathlon Principle is more likely to enable the translator to handle each aspect of translating songs and poems with higher precision, rather than focusing on one aspect at the cost of another. This is true for Pentathlon Approach when compared to Kaindl's Approach and Franzon's dichotomy of fidelity and format. More specifically, despite the fact that these last approaches are very interesting and give fertile related translation ideas, they are too broad and thus do not seem to do much with translating songs and poems. In addition, Low's approach is more flexible as he emphasizes the point that sense might be slightly adjusted so that the lexical items are more likely to fit the rhythm. He gives more room for the translator to maneuver the situation and reveal the creativity required. This is just an attempt. If the result of applying this approach failed, that will constitute one more proof that translating poetry is really untranslatable.

\section{Discussion}

As stated above, the translator should pay special attention to the two main factors that characterize this kind of poetic text. He/She is supposed to maintain a delicate balance between the content and the form or what was called "singability" (Low: 2015:185) that need to be dealt with carefully or sensitively in order to avoid problems or failure. Here are the Arabic songs along with their translation in English. The translation was done by the author. Stanzas were displayed in the following way for easy matching and juxtaposition:

1)

\begin{tabular}{|c|c|}
\hline $\begin{array}{l}\text { SL } \\
\text { يا سهر ان ليه السهران }\end{array}$ & $\begin{array}{c}\text { TL } \\
\text { You Wakeful Lover! } \\
\text { You Wakeful Lover! Why do you stay awake? }\end{array}$ \\
\hline ماللك فوق فرشك مقر & You do not have comfort on your bed. \\
\hline تذكر زمانك عبر & Remember the past time. \\
\hline حيا الله ذاك الزمان & How a wonderful time it was! \\
\hline 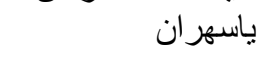 & You Wakeful Lover! \\
\hline قيا سهر ان اهدأ ونم & $\begin{array}{l}\text { You Wakeful Lover! Calm down and sleep. } \\
\text { Don't bear anxiety in your heart. }\end{array}$ \\
\hline 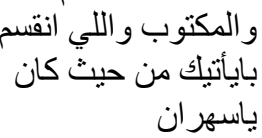 & $\begin{array}{l}\text { What was ordained } \\
\text { will surely come to you. } \\
\text { You Wakeful Lover! }\end{array}$ \\
\hline يا سيدر الد د خلك حفالك كفاك & You Wakeful Lover! What you suf \\
\hline
\end{tabular}




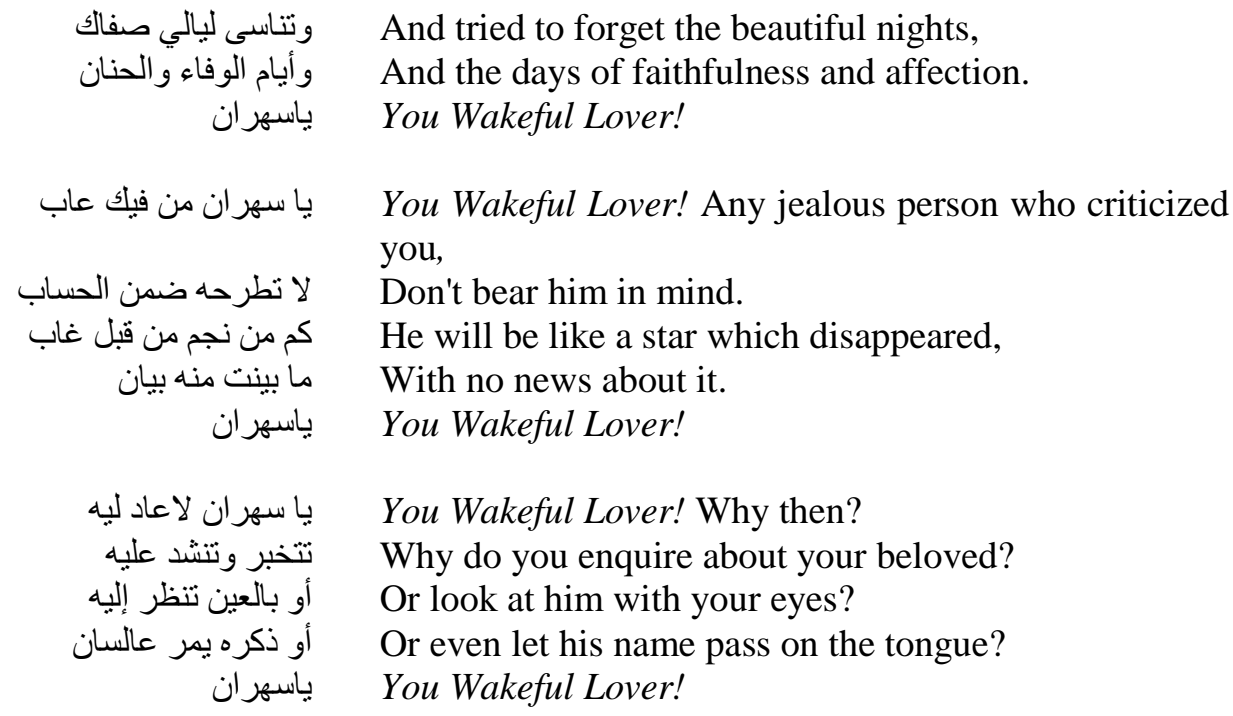

2)

SL

زماتك

ورى لي يحبوني بالأمس عادوني

ووققو ا حجر في طريق الحب من دوني

ور اهم تحدوني وز علو ا على شانك

زمانك زمانك يعر فلك بالناس ... وبالناس تعرف زمانكا

تجنو ا على وفي غييتي سبوني ويا ريتهم بعد ذاك السب سابوني

ولما يلاقوني يقولون خلانك

زمانك زمانك يعر فلك بالناس ... وبالناس تعرف زمانك

و هم كالعسل و اللبن من سمح ضروني وبعده سقوني من القاطع وضروني

ورجعو ا يحافوني على الفلس وراندانك

زمانك زمانك يعر فلك بالناس ... وبالناس تعرف زمانك
TL

\section{Your Time}

Why did those who loved me yesterday show enmity?

They stood as a stone on my way of love.

Why did they defy me and become jealous for your sake?

Your time, your time makes you know the people

and, with people, you know your time.

They oppressed and gossiped about me,

And I wish they left me after that.

But when they meet me, they wickedly say "we are your beloved".

Your time, your time makes you know the people

and, with people, you know your time.

They made me addicted to honey and milk.

Then they gave me wine and harmed me,

And they stingily treat me when it comes to a penny and a pound.

Your time, your time makes you know the people and, with people, you know your time. 
صحابي ولكنهم عابو اوباعوني فيا رب الأرباب ساعني وكن وكن وكن

عوني

وجد لَي بمضموني بلطفك و وإحسانك

زمانك زمانك يعر فلك بالناس ... وبالناس تعرف زمانك

إذا عزني الله هم مقصودهم هوني

بغونا نخب جم ونا أمشي على

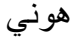

ومن خب جم في عظامه جاله الصانك

زمانك زمانك يعر فلك بالناس ... وبالناس تعرف زمانك

3)

\section{SL}

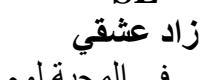

المحبة و لاشي في المحبة لوم

لاذكرته حبيبي مأ يجيني نوم لانية

و المسابيب يبغوني قنع وانسيه

كلما عانبوني زاد عشقي فيه

ظلم شلوا حبيبي واحرموني إياه

ظنوا اني إذا غاب باتناساه

لو عطوني الذهب .... الذهب مابيه

كلما عاتبوني زاد عشقي فيه

ما درى إيش يقصد مني الحاسد

ما درى أن قلب الحر له و احد

ان تتكد تتكد وان رضي يرضيه

كلما عاتبوني زاد عشقي فيه
They are my lovers, but they criticized and sold me.

Please my God help me,

And show mercy and kindness on me.

Your time, your time makes you know the people and, with people, you know your time.

When God made me great, they wish I became mean.

They wanted me to run too fast, while I walk at my ease,

But those who run too fast would stumble.

Your time, your time makes you know the people and, with people, you know your time.

TL

\section{My Love Increased}

It is love and there is no blame in love.

When I remember my beloved, I can't sleep.

The jealous people want me to forget her.

The more they blamed me, the more my love increased.

Unfairly, they took my beloved and deprived me of her.

They thought I will forget her if she is not around. Even if they gave me gold, I wouldn't accept it.

The more they blamed me, the more my love increased.

I don't know what the jealous person means.

He doesn't know that the free lover has one heart.

If this heart was unhappy, unhappy, or pleased pleased

The more they blamed me, the more my love increased.

Translating Saudi-Hadhrami folkloric songs and poems into English is not an easy task, not only because of their cultural features but also because of the very structural and semantic differences between Arabic and English. 
Romanticism and the feeling of liking, love, and caring are prevailing not only in these songs but also in most of Abu Bakr Salem songs (see Stocks and Maddock 1992).It is quite noticeable that the main theme of these three songs (You Wakeful Lover, Your Time, and My Love Increased) is mainly romantic. They speak about the affection and lover-beloved relationship. Entitling the first song with the phrase You Wakeful Lover and the third song with the phrase My Love Increased have succeeded in producing enough impact on the listeners and arouse their emotions. For instance, the theme of love has been quite obvious in the first two lines of song 1 as shown below.

\section{You Wakeful Lover! Why do you stay awake? م اللك فوق فرشك مقر لئر $\quad$ You do not have comfort on your bed.}

These two lines speak about the wakeful lover whose friends ask him why he keeps awake late at night. They say to him "We know the reason. It is because your heart and mind are all obsessed with thinking about the beauty of your beloved. You, therefore, get restless on your bed and sleep couldn't find its way to reach your eyes at night."

Indeed, despite the fact that Saudi-Hadhrami societies are traditional and conservative, this does not prevent poets and singers from writing and singing poems that deal with such romantic themes. This could be due to the fact that Arabs are, by nature, sentimentally sensitive and they enjoy songs and poems handling such ideas. These poetic texts give hints that the society is highly fascinated by these emotionally intriguing matters. Listeners play them at home and car, so these songs have become part of their daily chanted lyrics, repeatedly sung by laymen and women at home. These folk songs portray people's real situations and they, therefore, enjoy great popularity. See the beginning of the other lyric below.

$$
\begin{aligned}
& \text { Why did those who loved me yesterday show } \\
& \text { They stood as a stone on my way of love. } \\
& \text { دوني }
\end{aligned}
$$

The two lines above indicate how the lover speaks loudly to himself. He is complaining because his beloved misunderstood him yesterday. This incident has been exploited by his other "jealous" friends who started to antagonize and show hostility to him. He says they try to hinder all the lover's efforts to resume his love relationship with his beloved. They became like a big stone or obstacle on the way of the love journey. Similarly, the love theme is also clear in the first two lines of song 3 as stated below.

$$
\begin{aligned}
& \text { It is love and there is no blame in love. } \\
& \text { When I remember my beloved, I can't sleep. }
\end{aligned}
$$


Here, the lover is trying to disclose his romantic feeling to the public, confessing that he has fallen in love and asks all the friends to know this and stop blaming him. He bravely says his love is so strong and that he cannot sleep as long as he remembers his beloved.

It should be noted that the beloved refers to one's wife. In reality, women in Saudi-Hadhrami societies are similar in the sense that they are almost all veiled and are highly esteemed. People regard using the veil by ladies as a sign of respect. Ladies do not mix with men at work, schools, or marriage parties. They are mostly shy and kind in communication. They have their own family gettogethers which usually happen quite apart from the world of men. Therefore, when people think about romanticism which they hear in songs, they think about getting married at first as this is the only acceptable way for a man to officially meet the lady, so romanticism usually starts after marriage, not before. In summary, we can say that although the love theme is quite vivid in the overwhelming majority of Abu Bakr Salem songs, there is a quite considerable number of his songs that have religious and patriotic themes as well.

On the other hand, the translation above manages to convey the literal meaning, but it fails to transmit the cultural dimension. In Saudi-Hadhrami culture, for instance, keeping awake late at night is a further indication that the person has already found his romantic partner to whom he could get married, but this notion is most unlikely to be viewed in the same way in the English culture. This difference makes contributes to the belief that poetry is really untranslatable as it often fails to create an identical cultural image for the TL audience.

Moreover, the translator could not keep a similar rhyme and the same sound at the end of each line of the TL. Rhyme is the most important element of the prosodic features. Using rhyme gives beauty to the poem and it qualifies it to reach the degree required to fit the musical melody to be easily sung. Melody composers and singers usually reject handling poems with no accurate rhyme as this will cause difficulty for composers to fit the musical tunes into the wording of these poems. This will, consequently, have a negative reflection on the performance of the singer as well. Consider the example from song 1 below.

Stanza 1

Stanza 2

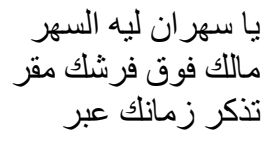

يا سهر ان اهدأ ونم

قالبك لا تحمله هم ألمي

و المكتوب و اللي انقسم
Wakeful! Why do you stay awake?

You do not have comfort on your bed.

Remember the past time.

Wakeful! Calm down and sleep.

Don't bear anxiety in your heart.

What was ordained

As seen above, all the Arabic lines have a similar rhyme in each stanza. However, rhyme in the English translation is observed to be completely missing. Searching for singable lexical items with the same rhyme seems to be something unattainable. The same thing is also true with regard to the other prosodic features 
like rhythm and meter. This goes in harmony with Low's approach (2005: 185) as he states "the making of singable translations is a very complex skopos because the target text must fit the pre-existing music - its rhythms, note-values, phrasings and stresses - while still retaining the sense of the source text." Thus, resorting to deviation and probable translation loss seems to be reluctantly unavoidable, so it seems true that "everything is translatable except poetry because it is the very form, the very phonetic quality of a poem in a language which makes a poem" Jakobson (as cited in Pirnajmuddin \& Medhat, 2011, p. 1330).

Religiously speaking, Arabs take certain things for granted. See the lines of the second stanza of song 1 below.

$$
\begin{aligned}
& \text { what was ordained }
\end{aligned}
$$

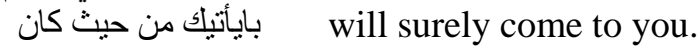

In the example above, the lover's friends try to soothe his anxiety after being forsaken by his beloved. They ask him to relax and sleep because, according to them, what was done cannot be undone and that one's destiny will surely happen. Success in love and marriage or any other things in life is something that is already ordained (مكتوب maktoob), so there is no need to worry about something that is beyond one's control. Actually, this is religiously taken for granted by Muslims, but this concept may contradict the attitude of English and western readers, especially those who are not so religious. The translator in such a case would be in a critical situation in the sense that the translator will be willing to add an explanatory note to clarify the intended meaning. He is, however, restricted by the form and the other prosodic features and he cannot do much to tackle the matter.

Furthermore, the wording of these songs contains rhythm and rhyme that are compatible with the Pentathlon Approach. However, reproducing similar ones in the TL with the same degree of precision is not effortless and a compensation method would be needed in an attempt to maintain the SL sense, singability, and naturalness.

It is worth mentioning that colloquialism is also a feature that manifested itself in the third song. For example, the lexical item مابيه mabih (I don't want it) is widely used in Saudi Arabic. The romantic poet expressed the idea that the lover is deeply indulged in love to the extent that if someone would give him gold instead of his beloved, he would not accept and would say mabih "I don't want it". Anyhow, the translator manages to render it into the TL properly. This gives rise to an issue that only the translator who belongs to the very SL colloquial culture can fully understand the source text and translate it as supposed and that translators who don't belong to this Saudi-Hadhrami culture will have a high possibility of producing imprecise rendition.

Agreeable redundancy has also been observed in the Arabic text of song 2 as shown below. 


\section{فيارب الأرباب ساعدني وكن Please my God help me, عوني}

The above Arabic line has the two verbal phrases ساعدني وكن عوني sa'edni and kun awni (help me). After the lover suffered a lot from his jealous friends' blame and severe criticism, he felt extremely annoyed and helpless not knowing what to do and how to behave to overcome this problem, so he asked Allah to help him. Both verbal phrases have the same meaning of help me. The second verbal phrase looks unnecessary and redundant. However, the poet added it for the sake of giving a proper poetic rhyme to suit this SL prosodic feature that can go in harmony with the previous line in that stanza. This is essential for the music of the SL song. Therefore, the translator used only one equivalent to cover the meaning of both verbal phrases to avoid causing unfavorable redundancy, but the rhyme was lost in the TL.

Moreover, the translator seems to have no choice and feels helpless and unable to control the musical problem that might happen in the TL version. In point of fact, musical mismatches have complicated the matter for the translator who struggles hard to meet the criteria of the Pentathlon Approach. The translation output may, as a result, look a bit unfaithful or suffers from a kind of inevitable prosodic and musical loss despite being aware that music and producing a singable translation constitute a vital part of the song according to Pentathlon. To sum up this point, retaining the song's musical features could be performed through the good choice of lexical items. However, that would always be at the cost of other linguistic features of the text.

\section{Conclusions}

Abu Bakr Salem's songs were chosen in this study as they reflect the daily rustic life of the simple society as well as because this singer has successfully managed to captivate the hearts of the local Arabs by his intriguing collection of songs and riveting melodies.

The study has shown some of the essential technical sides of translating folkloric songs, considering Low's (2005: 185) Pentathlon Approach's dimensions of sense, naturalness, singability, cultural references, and how these elements interact when putting them into practice.

To conclude, an essential factor was found to be unavoidable in translating songs. It lies in the fact that the function of translation determines the translation strategy used. That is, when the translator realizes that the poem was written for the purpose of singing, this shifts his/her focus into the form of the poem including; rhyme, rhythm, among other prosodic features and that often happens at the cost of the content (meaning). This has enacted a rule of translating poetry which is getting something that you want, but only by losing something else, bearing in mind that the SL content is semantically obscure as it may contain some lexical items that belong to the very deeply-rooted culture as well as the incompatibilities between the working concept systems of the languages involved. 
What adds insult to injury is that the poetry in question contains colloquially lexical items, a property that compels the translator to resist all kinds of restriction that can hinder his/her progress in manifesting the meaning intended. This is simply because these intricacies are more likely to back the translator into a corner and the colloquialism is hardly translatable, so one should expect that the translator's attempt might not arouse the TL response in a completely similar way as the one of the SL.

The present study has come to the conclusion that translating folkloric Saudi-Hadhrami songs is a complicated process and the intricacy lies in manifold dimensions including, cultural, musical, colloquial, prosodic, structural, and stylistic facets. The translator has done his best to preserve the aesthetic elements as far as possible to disclose the beauty hidden in these songs, a step in the right way towards raising translators' awareness in this regard. Handling this kind of text has greatly helped in revealing how Arabic and English vary in the representation of cultural, structural, social, and emotional dimensions. Consequently, the findings are that transiting folkloric Saudi-Hadhrami poems is a complicated process. Translators are not advised to translate poems because loss of meaning (content) or form becomes something unavoidable. The intricacies lie mainly in manifold dimensions including, cultural, colloquial, and prosodic aspects. As for Arabic songs, they are untranslatable because of the extra dimension of music which is beyond the translator's control. This goes in harmony with what Edward Said (1990) called the "embargo" on Arabic literature (See also Pirnajmuddin, Hossein and Vahid Medhat, 2011, and Lefevere, 1975).

\section{References}

Abdel-Hafez, Ahmed-Sokarno. (2004). 'Cultural elements in the translation of Mahfooz's 'the beginning and the end and palace of desire'. Internet Zeitschrift fur Kulturwissenschaften, 15. Retrieved on 17 February 2010, http://www.inst.at/trans/15Nr/07_1/abdelhafiz15.htm

Al-Azzam, Bakri and AladdinAl-Kharabsheh. (2011). 'Jordanian folkloric songs in translation: Mousa's song they have passed by without a company as a case study'. Meta, 56 (3): 557-578. https://doi.org/10.7202/1008333ar.

Al-Jabri, Hanan. (2019). "Recreating Tone in Two Arabic Translations of Landay Poetry". International Journal of Arabic-English Studies, 19: 446-459.

Al-Sabban, Abdulqader. (2001). Literary Movement in Hadhramout. Ministry of Culture. Al-Mukalla, Hadhramout.

Aminoroaya, Shiva and Zahra Amirian. (2016). 'Investigating the translation of songs in Persian dubbed animated movies'. Journal of Translation and Interpretation, 10 (2): 44-68. 
Anani, Mohammed. (2010). 'Sonnet 18: Shall I compare thee to a summer's day?' In Mustafa Mohammed: Forum of Arab Writers and Innovator, <http://www.almolltaqa.com/vb/archive/index.php/t-64408.html >

Anderson, Myrdene. (2005). 'The Saami Yoik: Translating Hum, Chant, or/and Song'. In Dinda L. Gorlée (ed.), Song and Significance: Virtues and Vices of Vocal Translation, 213-233. Amsterdam: Rodopi.

Dunbar, Dirk. (2002). 'The evolution of rock and roll: its religious and ecological themes'. Journal of Religion and Popular Culture, 2. Visited on 6 May 2010, <http://www.usask.ca/ relst/jrpc/article-evofrock.html .

Faiq, Said. (1998). 'Handling metaphor in sensitive texts: Contributions from Arabic-English translation'. Translation, 17(3): 224-239.

Farghal, Mohammed and Borini Ahmed. (1998). 'Pragmalinguistic failure and the translatability of Arabic politeness formulas into English: A case study of Mahfouz's awladharitna'. In Abdullah Shunnaq, Cay Dollerup and Mohammed Saraireh (eds.), Issues in Translation, Irbid: Deanship of Scientific Research, Irbid National University and Jordanian Translators' Association, 143-168.

Farghal, Mohammed and Abdullah Shunnaq. (1999). Translation with Reference to English and Arabic: A Practical Guide. Irbid: Dar Al-Hilal for Translation.

Franzon, Johan. (2005). 'Musical comedy translation: Fidelity and format in the Scandinavian My Fair Lady'. In Dinda L. Gorlée (ed.) Song and Significance: Virtues and Vices of Vocal Translation. Amsterdam: Rodopi, 263-297.

Ghazala, Hasan. (2002). 'Cross-cultural links in translation, English-Arabic'. International Journal of Translation, 14(1): 137-162.

Golomb, Harai. (2005). 'Music-linked translation (MLT) and Mozart's operas: Theoretical, textual and practical perspectives'. In Dinda L. Gorlée (ed.) Song and Significance: Virtues and Vices of Vocal Translation, Amsterdam: Rodopi, 121-161.

Gorlée, Dinda. (2005). Song and Significance. Virtues and Vices of Vocal Translation. Amsterdam: Rodopi.

Gritsenkoa, Elena and Evgeniya Aleshinskayab. (2016). 'Translation of song lyrics as structure-related expressive device'. Social and Behavioral Sciences, 231:165-172. DOI: 10.1016/j.sbspro.2016.09.087.

Hatim, Basil and Ian Mason. (1990). Discourse and Translator. London: Longman.

Homeidi, Moheiddin. (2004). 'Arabic translation across cultures'. Babel, 50 (1):13-27.

Jawad, Abdul Sattar. (2018). Shakespeare's Sonnets in Arabic. [Online], Durham. Available from <https://www.shakespeare.org.uk/exploreshakespeare/blogs/shakespeares-sonnets-arabic/>

Kaindl, Klaus. (2005). 'The plurisemiotics of pop song translation: Lexical items, music, voice and image'. In Dinda L. Gorlée (ed.) Song and Significance: Virtues and Vices of Vocal Translation. Amsterdam: Rodopi, 235-262. 
Kultti, Anne and Niklas Pramling. (2018). 'Behind the words: Negotiating literal/figurative sense when translating the lyrics to a children's song in bilingual preschool'. Scandinavian Journal of Educational Research, 62(2): 200-212, DOI: 10.1080/00313831.2016.1212261.

Lefevere André. (1975). Translating Poetry: Seven Strategies and a Blueprint, Assen: Van Gorcum.

Low, Peter. (2005). 'The pentathlon approach to translating songs. In Dinda L. Gorlée (ed.) Song and Significance: Virtues and Vices of Vocal Translation, Amsterdam: Rodopi, 185-212.

Pirnajmuddin, Hossein and Vahid Medhat. (2011). Linguistic deviation in poetry translation: An investigation into the English renderings of Shamlu's verse. Journal of Language Teaching and Research, 2(6), 1329-1336. DOI:10.4304/jltr.2.6.1329-1336.

Raffel, Burton. (1986). 'The manner of boyan: Translating oral literature'. Oral Tradition, 1 (1):11-29.

Robinson, Peter. (2010). Poetry \& translation: The art of the impossible. Liverpool:

University Press. Retrieved from http://books.google.ca.

Said, Edward. (1990) "Embargoed Literature" in The Politics in Dispossession:

The struggle of Palestinian Self Determination 1969-1994, New York: Pantheon. 372-8

Shunnaq, Abdullah and Fayez Abul-kas. (1998). 'Jordanian folkloric songs from Arabic into English'. Babel, 44 (2): 150-174.

Shunnaq, Abdullah. (2000). 'Arabic-English translation of political speeches'. Perspectives: Studies in Translatology, 8(3): 207-228.

Stocks, Michael and Andrew Maddock. (1992). Growing with Music. London: Longman.

Suharto, Suharto and Edi Subroto. (2014). 'The equivalence of translated songs lyrics and their effects - the case of translated ecclesial songs'. Harmonia: Journal of Arts Research and Education, 14 (2): 131-139.

Tagg, Philip. (2000). 'Analyzing popular music: theory, method, practice'. In Richard Middleton (ed.) Reading Pop: Approaches to Textual Analysis in Popular Music, 71-103. Oxford: Oxford University Press.

Vermeer, Hans. (1989/2000). 'Skopos and commission in translational activity'. In Lawrence Venuti (ed.) The Translation Studies Reader, London: Routledge, 221-232. 